\title{
Somatotroph/Lactotroph Adenoma
}

National Cancer Institute

\section{Source}

National Cancer Institute. Somatotroph/Lactotroph Adenoma. NCI Thesaurus. Code C127194.

A pituitary gland adenoma composed of acidophilic cells that produce both growth hormone and prolactin. It is characterized by the detection of growth hormone and prolactin within the same acidophilic cell, or an admixture of acidophilic and chromophobic cells that produce growth hormone and prolactin respectively. 